\title{
Bacterial-Type Contamination of Thachin River Water from Recharging Floodwater of Extreme 2011-Bangkok Flooding Disasters through the Three-Draining Canals
}

\author{
Sathapat Saneha, Kasem Chunkao, Narouchit Dampin, and Wit Tarnchalanukit
}

\begin{abstract}
Unnatural phenomena of five-consecutive typhoons in July through September 2011 caused the falling of heavy and long duration rain. The total rainfall turning to be streamflowed and reaching to around Bangkok about 150,000 MCM. Due to draining out of this amount of floodwater only Chao Phraya river took very long period of time, the government made the decision to take Mahasawad, Phasicharoen, and Mahachai canals to transfer them to Thachin river without any treatment before reaching to the stream water. In order to have warning sign from floodwater quality from unnatural typhoons in Thailand, the Royal LERD project had been collected floodwater sample to detect physical, chemical, and biological water quality at the areas around northern part of Bangkok, Chao Phraya river, three-canal watercourses (Mahasawad, Phasicharoen, Mahachai) and Thachin river. An analyzed value of physical and chemical quality was unpleasant because of high concentration above the surface water quality. As well as the biological water quality, especially microorganisms and water-born diseases was found much more than standard values [1]. It was no doubt that water of Thachin river had to be contaminated all the said water quality indicators which were rather lower quality than before and after transferring floodwater from upper north of Bangkok and Chao Phraya river through Mahasawad, Phasicharoen, and Mahachai canals to mix with Thachin river water. The above statement should be a lesson to learn of flood fighters not taking any action in the future because it would be like getting rid of bad thing from one place to the others on which it has been identified as plenty of natural resources likewise Thachin riverine systems [2].
\end{abstract}

Index Terms-Bacterial-type contamination, Thachin River, Bangkok flooding.

\section{INTRODUCTION}

Due to floodwater of 2011-flood event from Chao Phraya river by passing the 3 man-made canals (Klong Mahasawad, Klong Phasicharoen, and Klong Mahachai) to Thachin river was estimated more than a hundred million cubic meters together with high concentration of dissolved organic carbon, nitrogen, phosphorus, and sulfur as the number as organic solid wastes, toxic chemicals, microorganisms, and diseases. Consequently, these contaminants were expected to mix with Thachin river water one way or another and turning to carry them, at least, to estuarine and marine along the seashore along the west coast of the Gulf of Thailand with and without mangrove forest. Such phenomena could be hypothesized

Manuscript received November 10, 2012; revised January 12, 2013.

The authors are with the College of Environment, Kasetsart University, 50 Phahon Yothin Rd, Chatuchak Bangkok 10900, Thailand (e-mail: sathapatsaneha@hotmail.co.th). that these amounts of water and its quality should be affected to Thachin streamflow, especially salinity, electrical conductivity, $\mathrm{pH}$, total organic carbon, plant nutrients, heavy metals, pesticides, herbicides, fungicides, toxic chemicals, diseases, protozoa, microorganisms, suspended solids, total solids, sediment yields and some debris. Eventually, the estuarine and marine animals could not be tolerant to survive such fruitful habitat, some of them might be dead or migrated to another areas. So, the research is taken an DO Sag curve approach to obtain more or less results to answer the creative hypothesis in order to find the other means for managing floodwater of Chao Phraya river basin in the future if and only if it occurs.

\section{MATHERIAL AND METHOD}

\section{A. Study Area}

The experiment was conducted at the experimental site of flooding areas in part of the central in Ayuthaya, Chainat, Uthai Thani, Singhaburi, Lopburi, Angthong, Nontaburi, Saraburi, Bangkok, Nakhonpathom, Samutsakorn, and Samutsongkram provides including water sampling points, drainage canals and direction of floodwater draining out to the Gulf of Thailand.

\section{B. Localization of Sampling Sites}

Although the concentration of floodwater was somewhat homogenous because of long distance mixing from upper north through down north, upper central, central and north Bangkok, the sampling point distribution had to avoid micro-topographical effects along with three drainage canals and Thachin river. There were 5 sampling sites of equal distance among them along canals, and each site existed 5 sampling points about 300 meters apart while 7 sites was placed on Thachin river and each site was composed of 5 sampling points about 300 meters apart. In addition, the floodwater quality was sampled around stud area as located in north BangKok, Patum Thani and Ayutthaya detention storage and Thachin River for both the inflow and the outflow of the concerned systems as indicated in Fig. 2.

\section{Water Sampling Points}

The water sampling points were fixed at $30-\mathrm{cm}$ depth of every sampling points of each site for being understandable the water quality of canal and river, except the first upstream point collected water samples at three levels, i. e., 30-cm, 0.6 and 0.8 of the canal and river depths in order to evaluate water quality in vertical levels. There were four sampling 
lines for localizing the sampling points such as Klong Mahaswad, Klong Phasicharoen, Klong Mahachai and Thachin River. Each of the three canals (Klongs) was placed on five sampling points with equal length. For Thachin River, there were 21 sampling points to study the water quality.

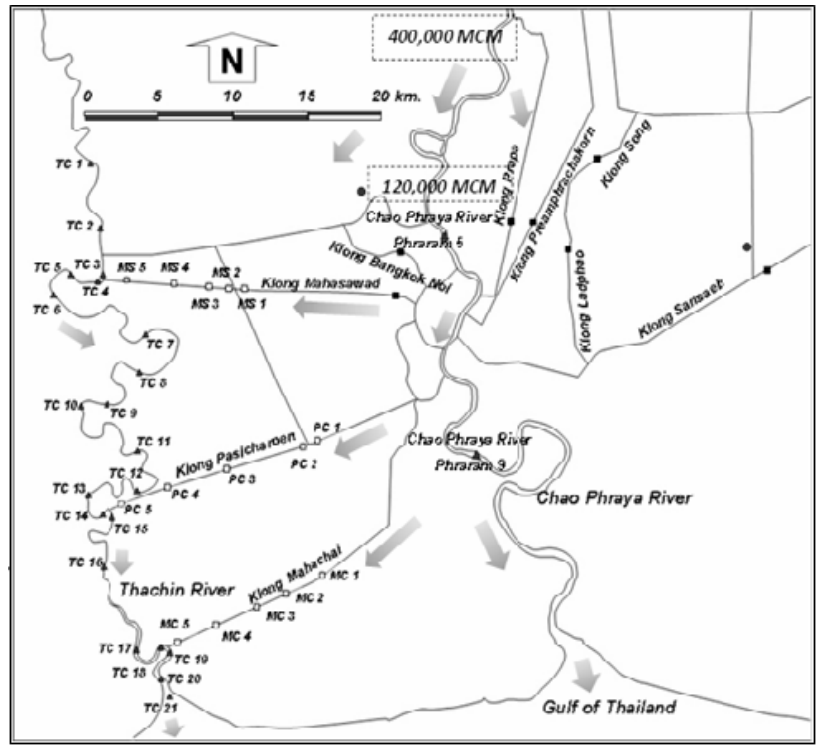

Fig. 1. Map of study area

\section{Field Measurement and Water Sample Collection}

\section{1) Field measurement}

Field measurement was taken an account of DO, pH, salinity, EC, TDS water temperature, ambient air temperature at every sampling points by using the DO meters, $\mathrm{pH}$ meters, salinity meters, electrical conductivity meters, total dissolved solid meters, and thermometers.

\section{2) Water sample collection}

Water sample were taken at the point $30-\mathrm{cm}$ depth collected in glass bottles with enough quantity for analyzing bacteria. Due to this study was real time research during huge flood around Bangkok and suburban areas of Patum Thani and Ayutthaya provinces and vicinity of Nakhon Pathom province on the date of January through late November 2012. Then the water collection had done for tree times: (1) the first water sampling period in January 2012, (2). the second in April 2012, (3) the third in November 2012.

\section{3) Laboratory analysis}

Floodwater collection in the glass bottles were used for analyzing the amount of bacterial groups by following the methods as written by APHA, AWWA, WEF [3].

\section{RESULT}

The biological analysis of water quality indexes at 9 measuring points obtained coliform bacteria 1,300 to $>160,000 \mathrm{MPN} / 100 \mathrm{ml}$, E.coli 79 to $22,000 \mathrm{MPN} / 100 \mathrm{ml}$, Fecal coliform 350 to $>160,000 \mathrm{MPN} / 100 \mathrm{ml}$, Total bacteria count $1.3 \times 10-4 \mathrm{CFU} / \mathrm{ml}$, and Vibrio cholera ND per $100 \mathrm{ml}$. All of those indicators had brought to decide that floodwater around Bangkok and suburban zones namely Nontaburi, Pathum Thani, and adjacent areas was identified as worse water quality, not suitable for touching them [4], [5].
Summarily speaking, the floodwater of Bangkok-Suburban point sources systems could decide for sure as the worsen quality whichever physical, chemical, or biological quality to use for serving any purposes, even for transportation [6], [7]. Draining out from the point sources would be valid but it needed to implement with care, otherwise the target areas had to confront both the tangible and intangible losses that took more periods of time for self recovery to the whole systems $[8]$.

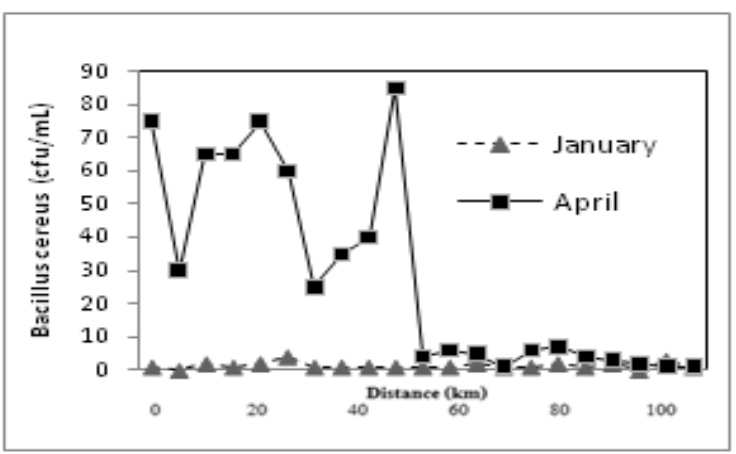

(a) Bacillus cereus of Thachin river as measured in January 2012 and April 2012

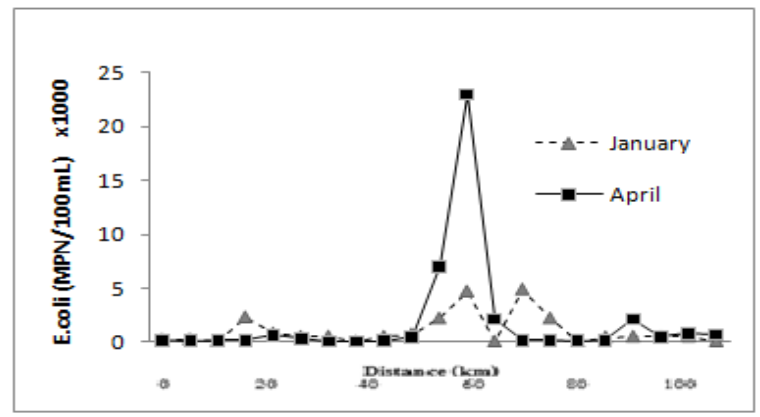

(b) Escherichia coli of Thachin river as measured in January 2012 and April 2012

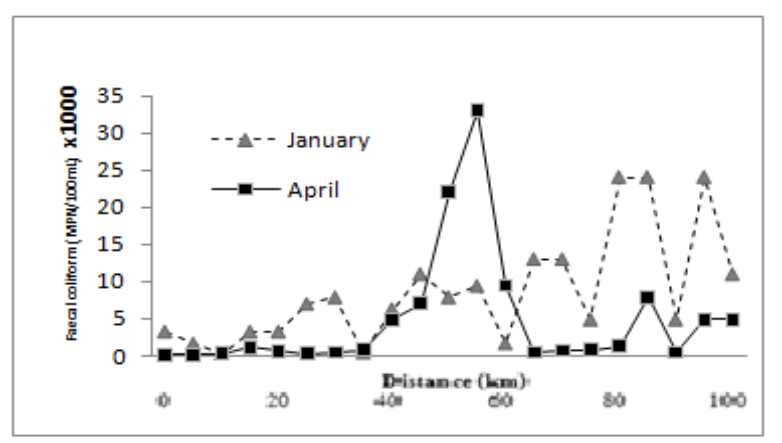

(c) Feacal coliform of Thachin river as measured in January 2012 and April 2012

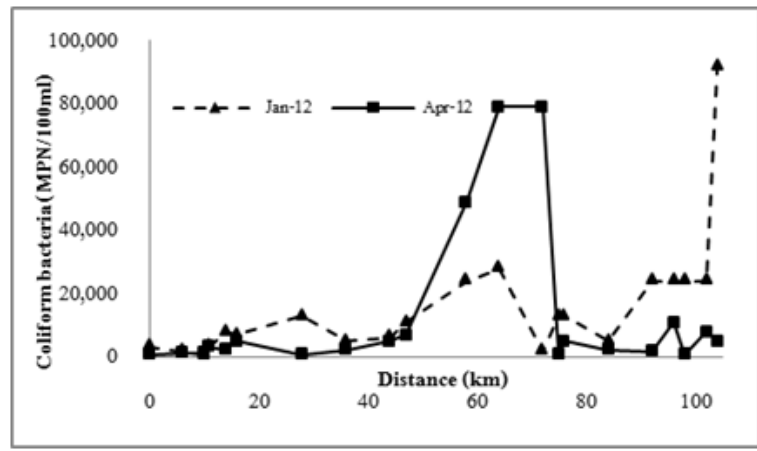

(d)Coliform bacteria of Thachin river as measured in January 2012 and April 2012 


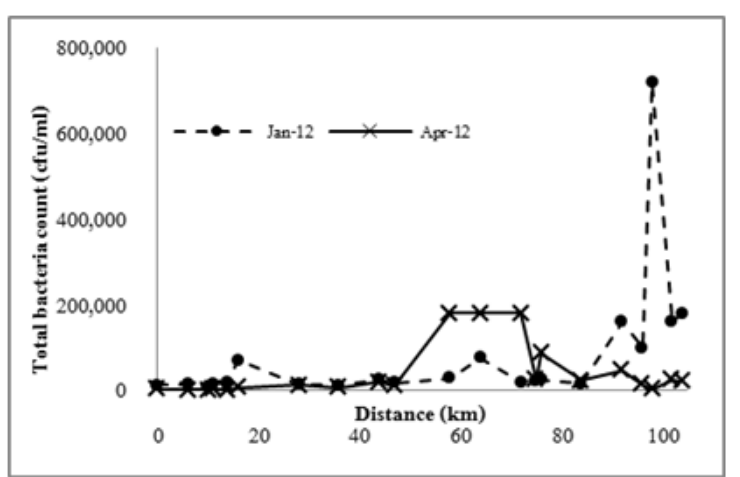

(e) Total bacteria count of Thachin river as measured in January 2012 and April 2012

Fig. 2. Patum Thani and Ayutthaya detention storage and Thachin river for both the inflow and the outflow of the concerned systems as indicated

\section{DISCUSSION}

According to much more contaminated floodwater from extremely 2011-Bangkok flooding disasters during September 2011 to February 2012 were approximately calculated 120,000 MCM storage on very wide bowl-shaped reservoir of northern Bangkok, Nontaburi, and Pathum Thani provinces which had to natural draining out by Chao Phraya river to the Gulf of Thailand, and expectedly very long period. This was why the decision making of government to transfer them through the 3-canal watercourses (Mahasawad, Phasicharoen, and Mahachai canals) into the Thachin river. The feasibility transferring should care for the floodwater quality, because the previous information concerning with Thachin river water had been found as pollution stream due to the inputs of various types of point sources, such as pig forms, food industries, along riverine houses, villages, cities. Seriously saying that the results of analyzed floodwater storage indicated the physical and biological water quality were mostly over surface water standard, especially salinity, DO, BOD, dissolved organic matters, microorganism diseases but no evident effects on chemical quality [9], [10]. Unfortunately, the 3-canal watercourses were characterized as contaminated canals due to localization of point sources as well. It is no doubt that draining of contaminant floodwater from Bangkok-Nontaburi-Pathum Thani storage through the 3-canal watercourses would be adding the pollutants one way or another. As expected earlier, solely Thachin river water has been found more or less contaminated river, particularly on about $100-\mathrm{km}$ reach between Nakhon Chaisi district down to the river mouth. In sofa, the data in April 2012 was shown the promising self purification, only some reaches found water quality lower standard but gradually increasing recovery capacity until at outlet as adjoined to the coastal zone. Evidently, the stream water almost turned to lower quality after receiving contaminated floodwater from the 3-canal watercourses. If possible, it ought not to pollute any contaminated water into Thachin river for any purposes. Fortunately, the zone about $10 \mathrm{~km}$ from the river mouth showed high efficiency on self purification [11].

\section{ACKNOWLEDGMENT}

The research is financed by the King's Royally Initiated
Leam Phak Bia Environmental Research and Developmental Project.

\section{REFERENCES}

[1] M. O. B. Coker and O. O. Ojior, "Effect of slaughterhouse wastes on the water quality of Ikpoba River, Nigeria," Bioresource Technology, vol. 52, pp. 5-12, 1995.

[2] K. Chunkao, Environmental Science, Fifth Edition, Kasetsart University Publishing, pp. 362, 2008.

[3] AWWA, Standard Methods for the Examination of Water and Wastewater, 21st ed. APHA, Washington, 2005.

[4] R. Campbell, Microbial Ecology, Blackwell Scientific Publications, London, pp. 148, 1977.

[5] P. A. Oluwande, M. K. C. Sridhar, A. O. Bammeke, and A. O. Okubadejo, "Pollution levels in some Nigerian Rivers," Water Res., vol. 17, no. 9, pp. 953-963, 1983.

[6] S. G. Hornor, "The effect of maniciple on microbial population of the Uillimantic/Shetucket river," M.S. Thesis, Connecticut University Citied, 1974.

[7] M. Ralph, Water Pollution Microbiology, Wiley Interscience, New York, pp. 416, 1972.

[8] A. Elosegui, X. Arana, A. Basaguren, and J. Pozo, "Self purification processes along a medium-sized stream," Environmental Auditing, vol. 19, no. 6, pp. 931-939, 1995.

[9] A. F. Carlucci and D. Pramer, "An evaluation of factors affecting the survival of Escherichia coli in seawater I," Applied Microbiology, vol. 8, pp. 243-247, 1960.

[10] J. J. Gannon, M. K. Busse, and J. F. Schillinger, "Fecal coliform disappearance in a river impoundment," Water Res., vol. 17, no. 11, pp. 1595-1601, 1983.

[11] K. Wuhrman, "Stream Purification," John Wiley and Sons, in Mitcell R. (ed.), Water pollution microbiology, New York, pp. 119-151, 1972.

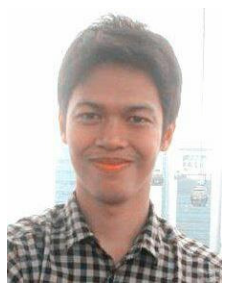

Sathapat Saneha was born on 15 March $1986 . \mathrm{He}$ was born in Trang province. He got Bachelor of Agro-industry (B. Sc.) from Prince of Songkhla university and is currently studying a Master's degree of Environmental Science (M.sc) in Kasetsart university. His experiences are Assist The research is financed by the King's Royally Initiated LeamPhakBia Environmental Research and Developmental Project.

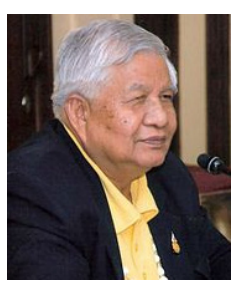

Kasem Chunkao was born on 23 April 1938. He was born in Sukhothai province. He got Ph.D. degree of Hydrology. He works as an professor at the King's Royally Initiated LeamPhakBia Environmental Research and Developmental Project and Dept of Environmental Science, Faculty of Environment, Kasetsart University.

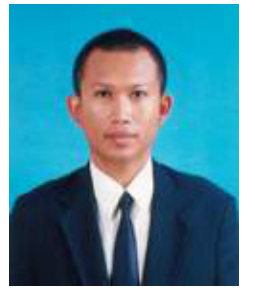

Narouchit Dampin was born on 19 Febuary 1971. He was born in Trang province. He got Ph.D. degree of Environmental science. He works as an lecturer at Dept of Environmental Science, Faculty of Environment, Kasetsart University.

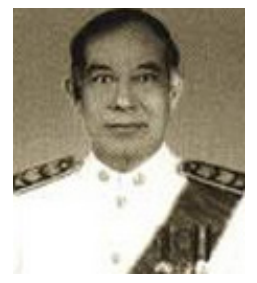

Wit Tarnchanukit was born on 4 April 1938.He was born in Bangkok. He got Ph.D. degree of Environmental science. He works as an lecturer at Dept of Environmental Science, Faculty of Environment, Kasetsart University. 